\title{
Assessment of Antioxidant and Sensory Properties of Amla (Emblica officinalis) Fruit and Seed Coat Powder Incorporated Cooked Goat Meat Patties
}

\author{
A.R. Bariya ${ }^{1 *}$, A.S. Patel ${ }^{1}$, V.V. Gamit ${ }^{2}$, K.R. Bhedi ${ }^{3}$ and R.B. Parmar ${ }^{4}$
}

${ }^{1}$ Department of Livestock Products Technology, ${ }^{2}$ Department of Livestock Production Management, ${ }^{3}$ Department of Veterinary Public Health and Epidemiology, College of Veterinary Science and Animal Husbandry, Junagadh Agricultural University, Junagadh-362001, Gujarat, India

${ }^{4}$ Division of Physiology and climatology, Indian Veterinary Research Institute, Izatnagar243122, Bareilly, U.P., India

*Corresponding author

\section{A B S T R A C T}

For fulfilling present national and international barriers regarding the use of chemical food additives in food processing and preservation, exploration for biological and plant derived

\section{Keywords}

Amla fruit extract, Seed COAT extract, Meat patties, Antioxidant

Article Info

Accepted:

24 June 2018

Available Online:

10 July 2018 food additives have also remarkably increased. So present study was imagined with the purposes to check the shelf life of goat meat patties incorporating with Amla fruits extract and Amla seed coat extract as natural preservatives and to assess their effect on physicochemical and sensory attributes of the product under vacuum packaged refrigerated $\left(4 \pm 1^{\circ} \mathrm{C}\right)$ storage. The products incorporated with Amla fruit extract and Amla seed coat extract had lower Thiobarbituric reacting substances (TBARS) value, free fatty acid (FFA) value and $\mathrm{pH}$ value than the control. As advancement of storage period total phenolic content was decreases. The sensory attributes like colour and appearance, flavour, juiciness and overall acceptability were decreased significantly $(\mathrm{p} \leq 0.05)$ as storage day advances. Sensory evaluation scores showed that goat meat patties incorporated with Amla fruits extract and Amla seed coat extract were equally acceptable as reference product and rated good to very good for colour and appearance, flavour, juiciness and overall acceptability. Goat meat patties with Amla fruit and its seed coat extract can be stored safely without much loss in its quality even up to 21 days under vacuum packed refrigerated storage.

\section{Introduction}

Problem of food preservation has grown more complex task become today and because new products launched in market requiring longer shelf life and greater assurance of protection from microbial spoilage. The development of many functional compounds helpful to human health is manufactured by processing of meat and meat products (Saiga et al., 2003; Vercruysse et al., 2005). Lipid oxidation as well as growth of objectionable 
microorganisms in food products results in the development of off flavour, rancidity, deterioration. Such products may become unacceptable for human consumption and also yield a many compounds that contribute to the pathogenesis of cancer, atherosclerosis, heart and allergic diseases (Bozin et al., 2007; Mielnik et al., 2008; Ibrahim et al., 2010).Several synthetic food additives have been widely used in the meat industry to overcome the objectionable changes. The meat industry is demanding antioxidants from natural sources to replace synthetic antioxidants because of the negative health consequences or beliefs regarding some synthetic ones. Compounds obtained from natural sources like grains, oil seeds, honey, fruits and vegetables have been investigated for their natural antioxidant and antimicrobial property in meat products. By products obtain after utilization of fruits and vegetables can offer a practical and economic source of strong antioxidants that could replace synthetic preservatives (Naveena et al., 2008). Amla (Emblica officinalis) as a Euphorbiaceous plant and is widely distributed in subtropical and tropical areas of China, India, Indonesia and Malaysia (Liu et al., 2008) which is used as a main ingredient in numerous Ayurvedic preparations for promotion of healthiness and longevity. Amla is a good source of polyphenols, flavones, tannins and mixture of bioactive compounds having strong antioxidants effect which leads to the health benefit effects. Numerous active compounds like gallic acid, ellagic acid, 1-Ogalloyl-D glucose, chebulininc acid, quercetin, chebulagic acid, kaempferol, mucic acid 1, 4lactone 3-O-gallate, isocorilagin, chebulanin, mallotusinin and acylatedapigenin glucoside have been isolated from the aqueous extract of Amla (El-Deousky et al., 2008). Amla contain active ingredients which are effective against pathogenic strains of Escherichia coli, Staphylococcus aureus, Klebsiella pneumonia, Pasteurella multocida, Streptococcus pyogenes, Vibrio cholerae, Pseudomonas aeruginosa (Patil et al., 2012; Javale and Sabnis, 2010; Mehrotra et al., 2010). The present study was conducted to assess the shelf life of goat meat patties added with amla fruit and its seed coat in vacuum packaged condition stored at $4 \pm 1^{0} \mathrm{C}$ as a natural preservatives.

\section{Materials and Methods}

\section{Procurement of materials}

Goat meat required for the study was procured from the meat shop located at Palanpur, Gujarat. Meat was brought in container covered with ice-bags and before processing it was stored at $4^{\circ} \mathrm{C}$ in refrigerator. Refined salt (Tata Chemicals Ltd., Mumbai), refined wheat flour, onion, garlic and ginger were procured from local market of Palanpur. Amla fruits were procured from Sardarkrushinagar Dantiwada Agricultural University, SDAU, Gujarat. Food grade chemicals were obtain from Merck and Qualigens.

\section{Preparation of powders and extracts}

Tap water was used to clean Amla fruits and to remove adhering dust then amla fruit were wiped with muslin cloth. The fleshy parts of Amla were nettled. Seed was detached manually from adhering Amla. Preliminary trail was carried out to know the temperature and time combination for drying of Amla and about $40-60^{\circ} \mathrm{C}$ for $48 \mathrm{hrs}$ was required for drying of Amla shreds in hot air oven. From each of the fragmented parts the seed coat was separated from the seed. The dried Amla fruit and seed coat were ground in laboratory grinder and passed through 60 mesh sieve and stored in LDPE pouches until used for the extraction. For extraction of Amla fruit extract and seed coat extract, $10 \mathrm{gm}$ of each powder were mixed in $100 \mathrm{ml}$ boiled water for 1 hrs.The extract obtained by filtration was 
analysed for total phenolic content, DPPH radical scavenging activity and also incorporated at different concentration in goat meat patties. For each replication freshly prepared extract were used.

\section{Preparation of goat meat patties}

The Goat meat was washed thoroughly and visible fat and connective tissue were removed. The deboned meat was cut into small cubes and minced in Stadler meat mincer using $8 \mathrm{~mm}$ plates and used for preparation of patties. Sodium chloride ( $2 \%)$, sodium tri-polyphosphate $(0.5 \%)$, spice mix (2\%), garlic paste (3\%), sunflower oil (3\%) and ice flakes $(8 \%)$ were used for preparation of patties.

Amla fruit extract were prepared by mixing 5, 10 and $15 \mathrm{gm}$ of powder in $100 \mathrm{ml}$ boiled water where as Seed coat extract were prepared by mixing 5, 10, 15 and $20 \mathrm{gm}$ of powder in $100 \mathrm{ml}$ boiled water and kept for 1 $\mathrm{hr}$ for extraction. $10 \mathrm{ml}$ of each extract were used for the preparation of Goat meat patties. On the basis of sensory evaluation, 10 gm extract of Amla fruit and $15 \mathrm{gm}$ extract of seed coat powder was optimize for preparation of patties. About $70 \mathrm{~g}$ of emulsion moulded to form patties and were cooked in a preheated oven at $180^{\circ} \mathrm{C}$ for 15 minutes after which they were turned and allowed to get cooked for 10 more minutes till internal temperature reached $75-80^{\circ} \mathrm{C}$.

Treatment with best sensory attributes was selected for further study for both Amla fruit extract and Seed coat extract incorporated patties. After cooling to room temperature the patties were vacuum packed in low density polyethylene bags and stored at refrigeration temperature $\left(4 \pm 1^{\circ} \mathrm{C}\right)$ for 21 days and analysed for total phenolic content, $\mathrm{pH}$, Free fatty acid value, TBA and sensory attributes at 3 days interval.
Analysis of Amla fruit and seed coat samples

\section{DPPH radical scavenging activity}

The capacity to scavenge 2, 2-diphenyl -1picrylhydrazyl (DPPH) radical by Amla fruit powder and seed coat powder was assessed(Brand Williams et al.,1995). $100 \mu \mathrm{l}$ of approximate dilution of sample / trolox solution was mixed with $3.9 \mathrm{ml}$ of freshly prepared DPPH working solution in $10 \mathrm{ml}$ test tube; the contents were mixed with vortex stirrer and incubated in dark for $120 \mathrm{~min}$ at $37^{\circ} \mathrm{C}$ after covering the test tube with aluminium foil. The absorbance of the solution was measured at $515 \mathrm{~nm}$ against methanol using Thermo Scientific Multiskan Go. Spectrophotometer. For blank determination $100 \mu \mathrm{l}$ methanol was taken in place of sample and absorbance was recorded immediately against methanol.

The results were expressed as:

$\%$ DPPH scavenging activity $=[(\mathrm{A} 515 \mathrm{~nm}$ blank - A 515nm sample)/ A 515nm blank] X 100

Results were expressed as trolox equivalent antioxidant capacity (TEAC) values i.e. $\mu \mathrm{mol}$ of trolox equivalent / gram of fruit weight.

\section{Total phenolics}

Total phenolic content in the Amla fruit powder and seed coat powder extracts was determined by modified Folin-Ciocalteu method (Kahkonen et al., 1999). $400 \mu l$ of approximate diluted sample / gallic acid standard was taken in a test tube. To it added $2000 \mu \mathrm{l}$ of diluted solution Folin-Ciocalteu's reagent and mixed with vortex mixer. After 3 minutes $1600 \mu \mathrm{l}$ of Sodium carbonate solution was added and incubated in dark at room temperature for $30 \mathrm{~min}$. For blank preparation 
$400 \mu \mathrm{l}$ of distilled water was taken instead of sample. The absorbance of the sample was measured against blank at $765 \mathrm{~nm}$ using Thermo Scientific Multiskan Go. Spectrophotometer.

\section{Analysis of meat patties samples}

\section{pH}

For determining the $\mathrm{pH}$ of meat samples Method of Trout et al., (1992) was followed. Meat sample $(10 \mathrm{~g})$ was blended with $50 \mathrm{ml}$ distilled water for 1 minute using pestle and mortar. The $\mathrm{pH}$ was recorded by dipping the electrodes of $\mathrm{pH}$ meter directly in suspension.

\section{Total phenolics}

Total phenolic content in cooked goat meat patties was determined by modified FolinCiocalteu method (Negi and Jayaprakasha, 2003). $5 \mathrm{~g}$ of cooked patty was homogenized with $25 \mathrm{ml}$ of $70 \%$ acetone and kept overnight for extraction in refrigeration condition. Appropriate aliquots of extracts were taken in a test tube and the volume was made to $0.5 \mathrm{ml}$ through distilled water followed by the addition of $0.25 \mathrm{ml} \mathrm{F-C}(1 \mathrm{~N})$ reagent and 1.25 $\mathrm{ml}$ sodium carbonate solution $(20 \%)$. The tubes were vortex and the absorbance recorded at $725 \mathrm{~nm}$ after $40 \mathrm{~min}$. The amount of total phenolics was determined as Gallic acid equivalent against the calibration curve using $0.1 \mathrm{mg} / \mathrm{ml}$ of standard gallic acid solution.

\section{Thiobarbituric reacting substances (TBARS) value}

Thiobarbituric acid reacting substances (TBARS) value was followed for determine the lipid oxidation. Method of Witte et al., (1970) was followed for Thiobarbituric acid (TBA) value. Minced meat (5 g) was blended for 3 min with $25 \mathrm{ml} 20 \%$ TCA. Slurry was kept for $10 \mathrm{~min}$. it was filtered through Whatman No. 42 filter paper. \% $\mathrm{ml}$ of TBA reagent was added to $5 \mathrm{ml}$ of sample aliquot (filtrate). After mixing the contents, tubes were held for $35 \mathrm{~min}$ in a boiling water bath. Optical density was measured at $532 \mathrm{~nm}$ spectrophotometrically. Blank was run simultaneously for standard curve 1, 2, 3, 4, 5 $\mathrm{ml}$ of working standard solution were used.

\section{Sensory evaluation}

Semi trained taste panel, which includes professor and post graduate students of the LPT department obliged in conducting the sensory evaluation of the product. They were requested to give their desire on 9 point hedonic scale for attributes like colour and appearance, flavour, juiciness and overall acceptability. Where $9=$ Like extremely, 8 $=$ Like very Much, $7=$ Like moderately, $6=$ Like slightly, $5=$ Neither like nor dislike, $4=$ Dislike slightly, 3= Dislike moderately, 2 = Dislike very much, 1 = Dislike extremely. Patties were pre warmed before serving and water was served for rinsing the mouth between samples.

\section{Statistical analysis}

The results were statistically analysed as per the methods described by Snedecor and Cochran (1989). The significant treatment effects, upon all profiles were tested using Duncan's multiple range test with $\mathrm{p} \leq 0.05$ by SPSS software. Two-way analysis of variance was used to evaluate the results of the storage studies to determine the effect of treatment and storage period.

\section{Results and Discussion}

\section{Total phenolics content and DPPH radical scavenging activity}

Result of total phenolics content and DPPH radical scavenging activity of Amla fruit and Seed coat extract are presented in figure 1 and 2 as well as in table 1. There was no 
significant difference $(p \geq 0.05)$ found for DPPH scavenging activity of Amla fruit extracts and seed coat extracts. The total phenolic content of seed coat was relatively lower than Amla fruit. Highest antioxidant activity observed for Amla in the present study might be due to the high content of vitamin $\mathrm{C}$ and other compounds which have antioxidant activity. Estimation of total phenolic content of Amla fruit was done by different worker (Ayubali et al., 2010; Agarwal et al., 2012; Luqman and Kumar, 2012). Ayubali et al. found 1285.63 total phenolic content (mg GAE /100 g) for Amla fruit which is similar to the polyphenol content of Amla fruit used in the present study. Estimation of total phenolic content of seed coat was done by Mishra and Mahanta (2014) and found $593.06 \mathrm{mg} \mathrm{GAE} / 100 \mathrm{~g}$. The differences of total phenolic content of fruit and seed coat could be due to different preparations and extraction method. Mishra and Mahanta (2014) also found that DPPH radical scavenging activity for Amlafruit and seed coat showed lower difference than the seed part of the Amla.

\section{pH}

The $\mathrm{pH}$ value of all patties samples slightly decreased during the first 9 days whereas after day 9 there was a gradual increase. The $\mathrm{pH}$ value of vacuum packaged goat meat patties are presented in Figure 3. $\mathrm{pH}$ decreased for a period of 9 days might be due to the production of LAB metabolism which was favoured by the low oxygen environment (Gok et al., 2008; Karabagias et al., 2011). Increase in $\mathrm{pH}$ during storage in vacuum packaged products is reported by Sinhamahapatra et al., (2013) in chicken meat ball. In contrast Irkin et al., (2011) found that declining in $\mathrm{pH}$ of vacuum packaged product during entire period of storage in minced beef meat.

\section{Total phenolic content}

Total phenolic content of control and both extract incorporated meat patties during storage at refrigeration temperature $\left(4 \pm 1^{0} \mathrm{C}\right)$ are presented in figure 4 . At the 21 st days in vacuum packaged patties lowest value was observed for control patties than both extract incorporated meat patties. In vacuum packaged patties significant $(\mathrm{p} \leq 0.05)$ decrease in total phenolic content was found after 3 days in both control and extract incorporated meat patties with advancement of storage period. However Amla fruit extract incorporated patties had the highest phenolic content on day 21 in vacuum packaging. Decrease in a phenolic content of patties might be due to the heating of the patties during the sensory evaluation at three days interval and heating leads to loss or denaturation of the some phenolic content in patties. The Naveena et al., (2008) in cooked chicken patties; Devatkal et al., (2010b) in goat meat patties; Verma et al., (2013) in sheep meat nuggets and Serdaroglu et al., (2015) in raw beef pattiesfound similar results with present findings. The higher level of phenolics may indicate patties is nutritionally enhanced due to the fruit extract and seed coat extract that was added (Leheska et al., 2006).

\section{TBA value}

There was an increase in TBA value in vacuum packaged both control and extract incorporated meat patties during storage. At the $21^{\text {st }}$ day of storage control patties had higher TBA than both extract incorporated meatpatties. TBA values of goat meat patties incorporated with Amla fruit extract and Seed coat extract are presented in figure 5 . There was a significant $(\mathrm{p} \leq 0.05)$ linear increase in TBARS values with increase in the storage period which remained well below threshold value of $1 \mathrm{mg}$ malonaldehyde/ $\mathrm{kg}$ of meat sample on both aerobic as well as vacuum packaging during storage. In vacuum 
packaged patties TBA increased significantly $(\mathrm{P} \leq 0.05)$ with increase in storage period but found low which might be due to vacuum inside PET material which act as efficient barrier to oxygen and inhibit lipid oxidation. Degirmencioglu et al., (2012) in minced meat and Hur et al., (2013) in low grade beef reported similar results in vacuum packaged products. The concentrations of TBA value in treatment was considerably lower than the control and seed coat extract incorporated patties and it indicated a significant relation between phenolic content and antioxidant effect of Amla fruit extract in protecting against lipid oxidation of patties.

\section{Free fatty acid}

There was a gradual increase in free fatty acid contents in vacuum packaged both control and extract incorporated meat patties during storage. Free fatty acid content also showed increasing trend throughout storage. Value of free fatty acid contents are presented in figure 6. However, it was higher in control than both treatments even on the first day of storage of patties. It might be due to the antioxidant effect of Amla fruit extract (Khopde et al., 2001; Charoenteeraboon et al., 2010) and Seed coat extract (Mishra and Mahanta, 2014). Vacuum packaging increase the self-life of product which might be due to the absence of the $\mathrm{O}_{2}$ in vacuum packaged product which is considered as chelating agent for lipid oxidation (Ahn et al., 1998). Similar result was found by Kumar et al., (2015) in pork patties added with combination of natural antioxidants using combination of packaging methods.

\section{Sensory evaluation of goat meat patties}

\section{Colour and appearance scores of meat patties}

The colour and appearance score of vacuum packaged control and extract incorporated goat meat patties are presented in Figure 7. Declining trend in colour and appearance was observed for both control and extract incorporated patties.

The decrease in colour and appearance score of patties might be due to the oxidation of lipid and pigment which lead to the nonenzymatic browning (Che-man et al., 1995) as well as surface dehydration. Similar decline in colour and appearance score during storage have been reported by Zargar et al., (2014) in a chicken sausages; Najeeb et al., (2014) in restructured chicken slices and Giriprasad et al., (2015) in restructured buffalo meat steaks.

\section{Flavour scores of meat patties}

In vacuum packaged patties up to 6 days there was no significant change in flavour score was noticed but after that decline in flavour was observed as storage period advanced.

The flavour score of vacuum packaged control and extract incorporated goat meat patties are presented in Figure 8. The flavour score for all patties were reported by panellists which were within the acceptable range. It was also noticeable that decline in flavour of control patties was comparatively more than treatment groups.

The decrease in flavour score in patties may be due to the microbial growth and oxidative spoilage as showed by TBARS numbers. Tarladgis et al., (1960) described that TBARS values were highly correlated with sensory scores of trained panellist. Similar declining in flavour score during storage reported by Thomas et al., (2006) in buffalo meat nuggets; Zargar et al., (2014) in a chicken sausages; Najeeb et al., (2014) in restructured chicken slices and Giriprasad et al., (2015) in restructured buffalo meat steaks. Similar result was found by Gomez and Lorenzo (2012) in foal steaks which were packed under various conditions. 
Table.1 Total phenolics content and DPPH radical scavenging activity of Amla fruit and Seed coat extract

\begin{tabular}{|l|c|c|}
\hline \multicolumn{1}{|c|}{ Extract } & $\begin{array}{c}\text { DPPH radical scavenging activity }(\mu \mathrm{mol} \\
\text { TE/g) }\end{array}$ & $\begin{array}{c}\text { Total phenolic content }(\mathrm{mg} \text { GAE } \\
/ 100 \mathrm{~g})\end{array}$ \\
\hline $\begin{array}{l}\text { Amla fruit } \\
\text { Amla Seed } \\
\text { coat }\end{array}$ & $21.18 \pm 0.30^{\mathrm{c}}$ & $1164.83 \pm 1.77^{\mathrm{d}}$ \\
\hline $\begin{array}{l}\text { Mean } \pm \text { S.E, } \mathrm{n}=3 \\
\text { Mean } \pm \text { S.E with different small letter superscripts in rows within each parameter differ significantly }(\mathrm{p} \leq 0.05) ; \mathrm{n}=6\end{array}$
\end{tabular}

Figure.1 DPPH radical scavenging activity of Amla fruit and Seed coat extract

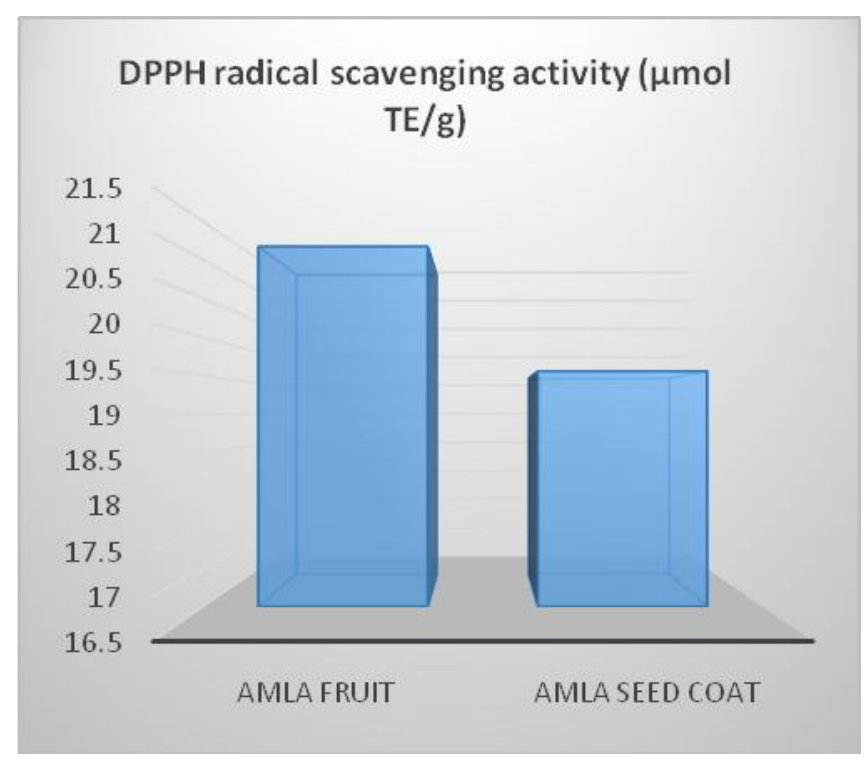

Figure.2 Total phenolics content Amla fruit and Seed coat extract

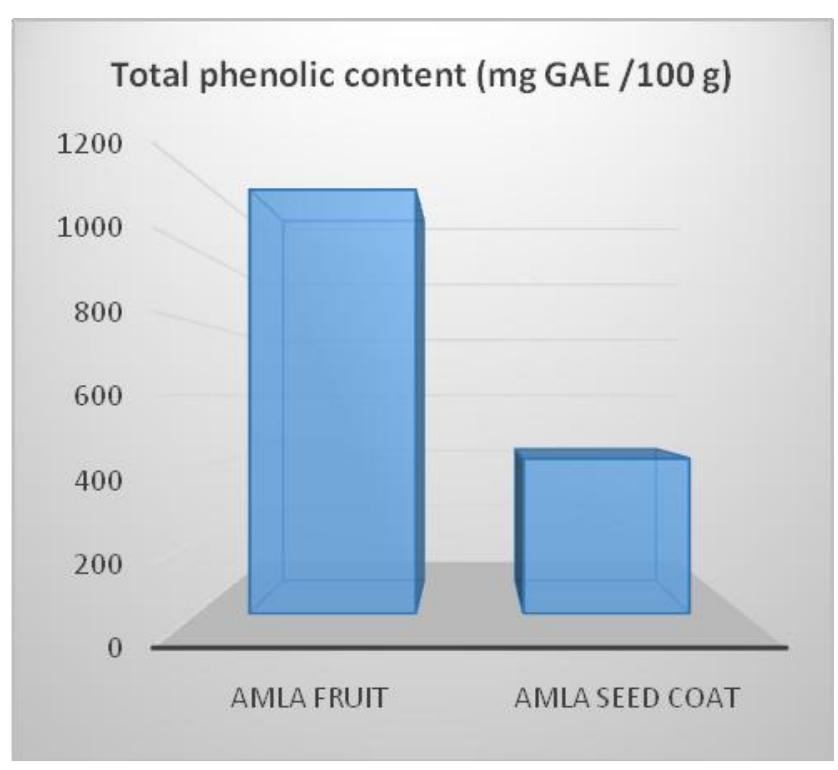

Figure.3 Effect of storage on $\mathrm{pH}$ of vacuum packaged patties

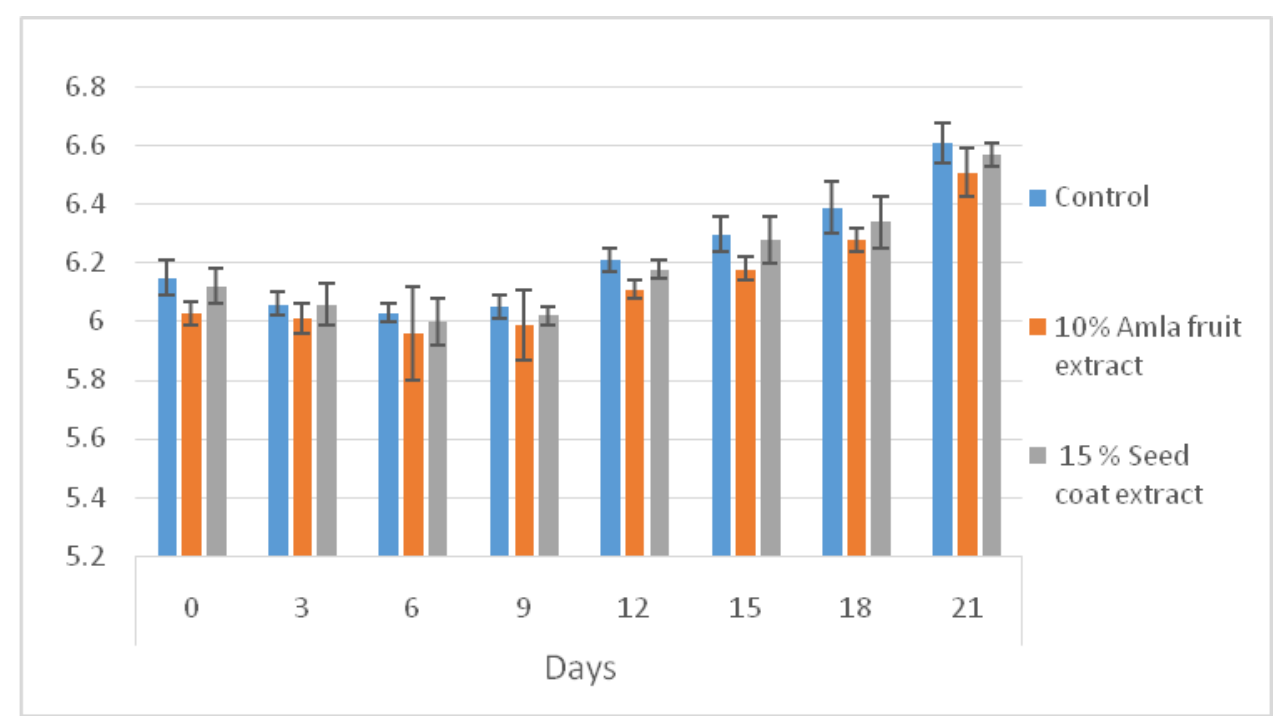


Figure.4 Effect of storage on total phenolic content of vacuum packaged patties

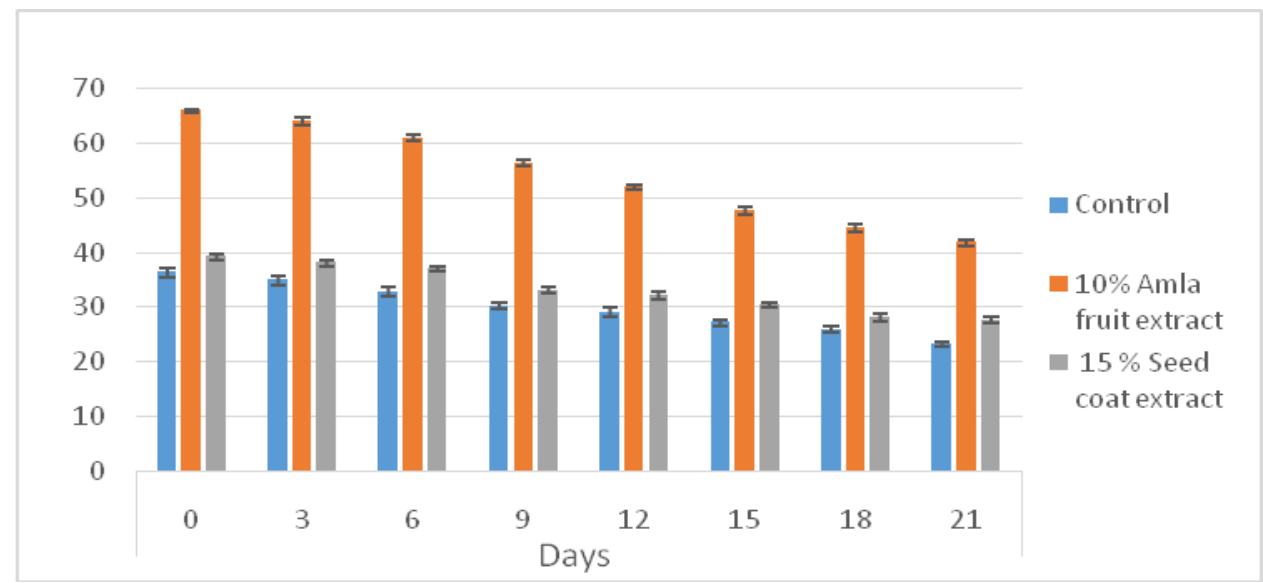

Figure.5 Effect of storage on TBA value of vacuum packaged patties

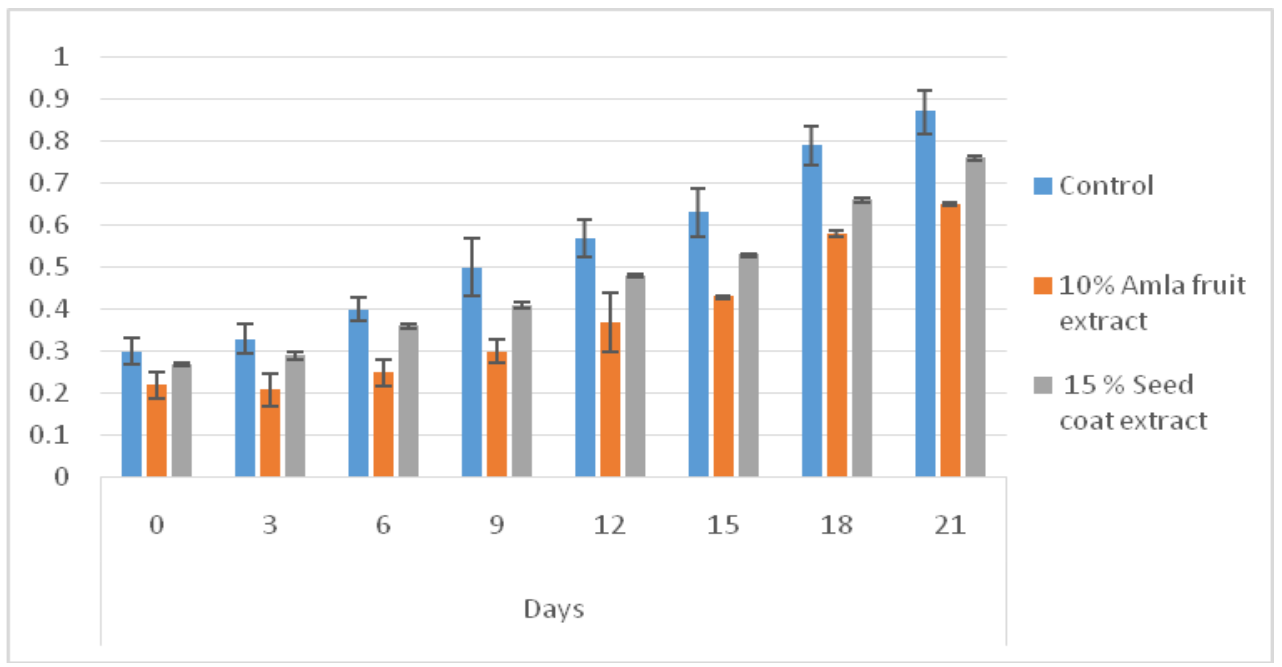

Figure.6 Effect of storage on free fatty acid of vacuum packaged patties

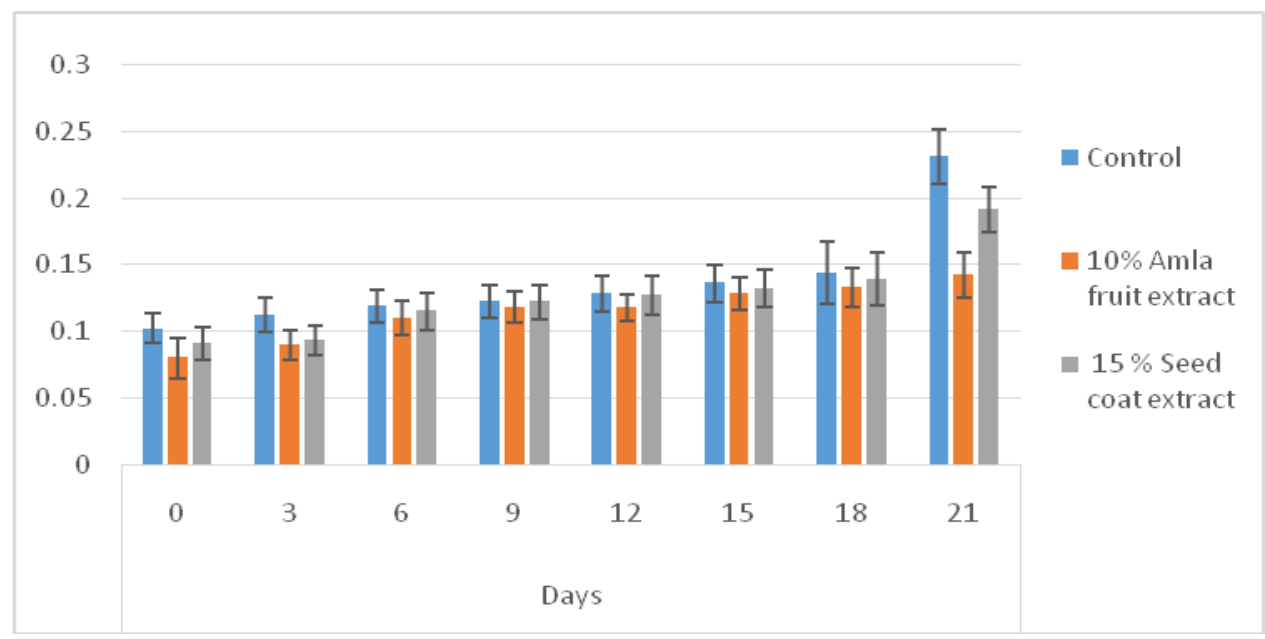


Figure.7 Effect of storage on Colour and appearance score of vacuum packaged patties

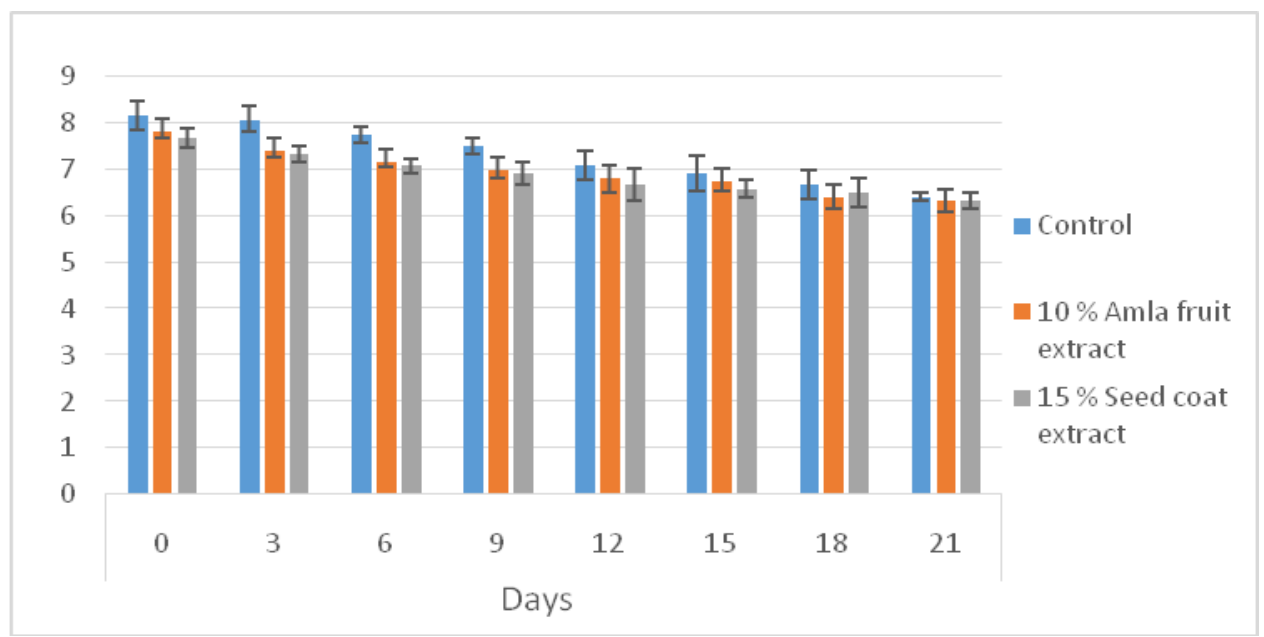

Figure.8 Effect of storage on flavour score of vacuum packaged patties

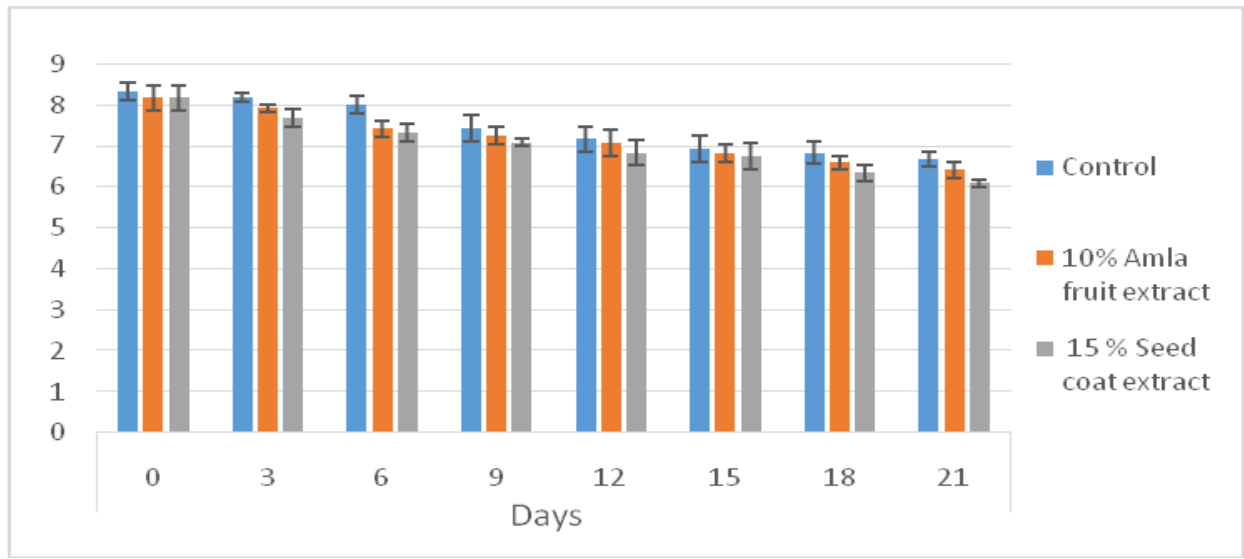

Figure.9 Effect of storage on juiciness score of vacuum packaged patties

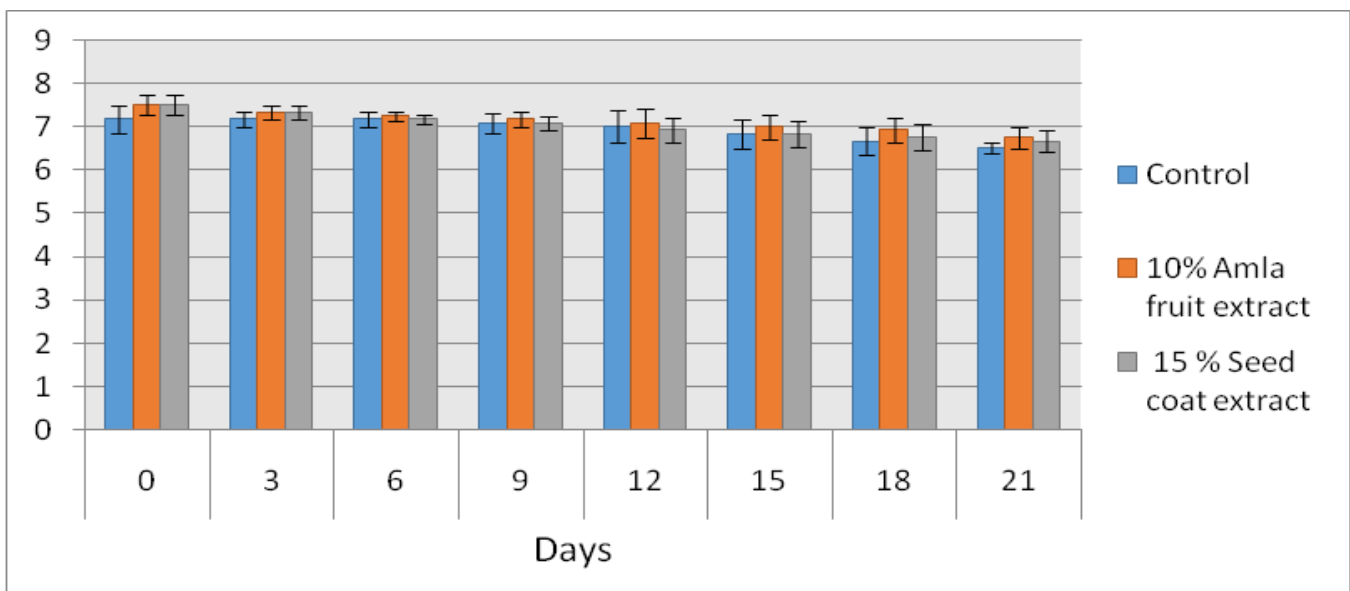

Figure.10 Effect of storage on overall acceptability score of vacuum packaged patties 


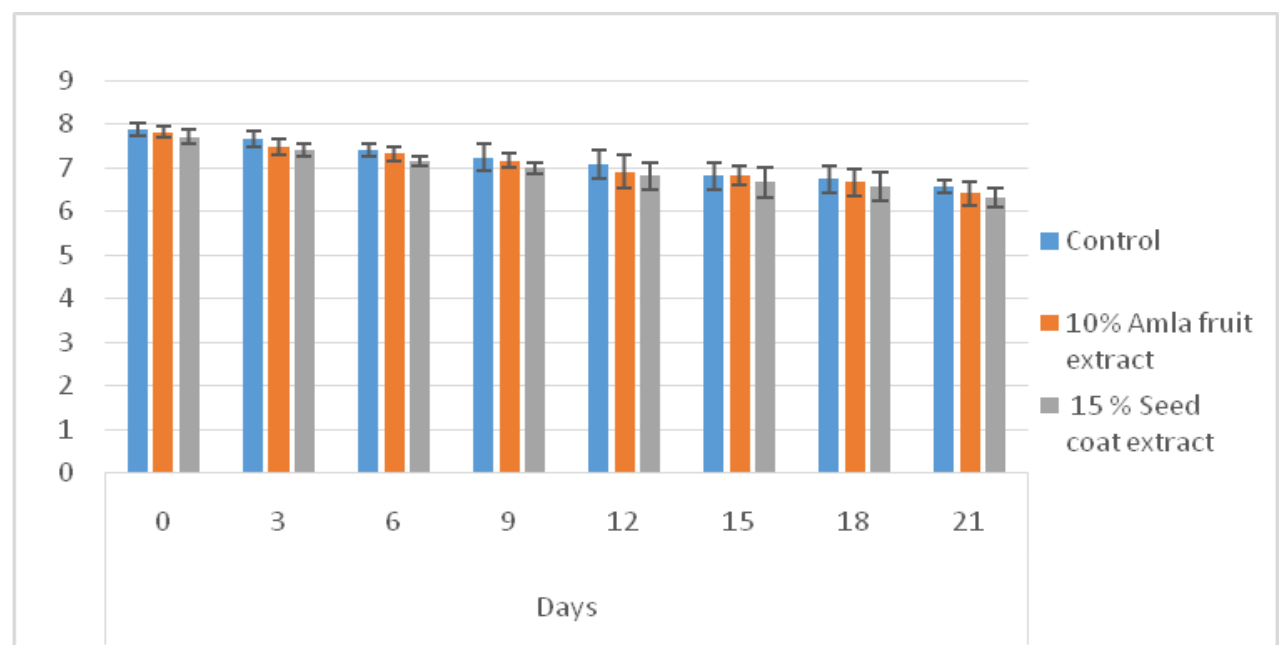

\section{Juiciness scores of meat patties}

The juiciness score of vacuum packaged control and extract incorporated goat meat patties are presented in Figure 9. Mehta et al., (2015) and Biswas et al., (2011b) in chicken and duck meat patties, respectively stored at refrigeration temperature $\left(4 \pm 1^{0} \mathrm{C}\right)$ and found that juiciness score was better in vacuum packaged meat patties using PET due to impermeability of packaging material. Bhuvana et al., (2012) and Giriprasad et al., (2015) also found that there is decrease in juiciness with advancement of storage period in pork fry and restructured buffalo meat steaks, respectively.

\section{Overall acceptability scores of meat patties}

A decrease in overall acceptability during storage was observed in control as well as in treated patties as storage period advances. The juiciness score of vacuum packaged control and extract incorporated goat meat patties are presented in Figure 10.

Similar trends of reduction in overall acceptability scores at the end of storage period have also been reported by Indumathi and Obula Reddy (2015) in Chicken meat nuggets added with three different antioxidant extracts ( $1 \%$ level) of curry leaf, guava leaf and green tea and Giriprasad et al., (2015) in restructured buffalo meat steaks added with Amla powder. Rajkumar et al., (2004) and Hur et al., (2013) also stated that vacuum packaging had definite advantage in preserving sensory quality of goat meat patties and low grade beef, respectively.

In conclusion, finding of the study revealed that Amla fruit and its seed coat powder can be used as natural antioxidant source in cooked goat meat patties. This natural antioxidants source is a good replacement for synthetic antioxidants.

\section{References}

Agarwal, M., Kumar, A., Gupta, R. and Upadhyaya, S. 2012. Extraction of Polyphenol, Flavonoid from Emblica officinalis, Citrus limon, Cucumis sativus and Evaluation of their Antioxidant Activity. Oriental Journal of Chemistry. 28(2): 993-998.

Ahn, D. U., Olson, D. G., Lee, J.I., Jo, C., Wu, C. and Chen, X. 1998. Packaging and irradiation effects on lipid oxidation and volatiles in pork patties. Journal of Food Science. 49(1):27-39 
Ayub Ali, M., Inaotombi Devi, L., Nayan, V., Chanu, K. V. and Ralte, L. 2010. Antioxidant activity of fruits available in aizawl market of Mizoram, India. International Journal of Biological and Pharmaceutical Research. 1(2): 76-81.

Bhuvana, K. S., Mandal, P. K. and Pal, U. K. 2012. Garciniacambogia fruit extract enhance the self-life of pork fry in room temperature. International Journal of Meat Science. 2(2):27-33.

Bozin, B., Mimica-Dukic, N., Samojlik, I. and Jovin, E.A. 2007. Antimicrobial and antioxidant properties of rosemary and sage (Rosmari nusofficinalisL. and Salviaofficinalis L., Lamiaceae) essential oils. Journal of Agricultural and Food Chemistry.55: 7879-7885.

Brand Williams, W., Cuvelier, M.E. and Berset, C.L.W.T. 1995. Use of a free radical method to evaluate antioxidant activity. Food Science and Technology. 28: 2530.

Charoenteeraboon, J., Ngamkitidechakul, C., Soonthornchareonnon, N., Jaijoy, K. and Sireeratawong, S. 2010. Antioxidant activities of the standardized water extract from fruit of Phyllanthusemblica Linn. Songklanakarin Journal of Science and Technology. 32(6): 599-604.

Che Man, Y.B., Bakar, J. and Mokri, A.A.K. 1995. Effect of packaging films on storagestability of intermediate deepfried mackerel. Int. J. Food. Sci. Technol., 30:175-179.

Degirmencioglu, N., Esmer, O. K., Irkin, R. and Degirmencioglu, A. 2012. Effect of vacuum and modified atmospheric packaging on shelf life extension of minced meat chemical and microbial changes. Journal of Animal and Veterinary Advances. 11(7): 898-911.

Devatkal, S. K., Narsaiah, K. and Borah, A. (2010b). Anti-oxidant effect of extracts of kinnow rind, pomegranate rind and seed powders in cooked goat meat patties. Meat Science.85:155-159.

El-Deousky, S.K., Ryu, S.Y. and Kim, Y.K.
2008. A new cytotoxic acylatedapigenin glucoside from Phyllanthus emblica L. Natural Product Research. 22: 91-95.

Giriprasad, R., Sharma, B. D., Kandeepan, G., Mishra, B. P. and Yasothai, R. (2015). Shelf life evaluation of functional restructured buffalo meat steaks fortified with Mousambi peel powder and Amla powder at refrigerated storage $\left(4 \pm 1^{\circ} \mathrm{C}\right)$. International Food Research Journal. 22(4): 1446-1453.

Gok, V., Obuz, E. and Akkaya, L. 2008. Effect of packaging method and storage time on the chemical, microbiological and sensory properties of Turkish pastirma-a dry cured beef product. Meat science.33:114-125.

Gomez, M. and Lorenzo, J. M. 2012. Effect of packaging conditions on shelf-life of fresh foal meat. Meat Science.91: 513520

Hur, S. J., Jin, S. K., Park, J. H., Jung, S. W. and Lyu, H. J. 2013. Effect of modified atmosphere packaging and vacuum packaging on quality characteristics of low grade beef during cold storage. Asian-Australasian Journal of Animal Sciences. 26(12): 1781-1789.

Ibrahim, H.M., Abou-arab, A. A. and Abu Salam, F. M. (2010).Addition of some natural plantextract and their effects on lamb patties quality. Journal of Food Science and Technology.8:134-142.

Indumathi, J. and Obula Reddy, B. 2015. Effect of different natural antioxidant extracts on the shelf life of functional chicken meat nuggets. International Journal of Advanced Research.3(6): 820-828.

Irkin, R., Esmer, O. K., Degirmencioglu, N. and Degirmencioglu, A. 2011.Influence ofpackaging conditions on some microbial properties of minced beef meat at $4{ }^{\circ} \mathrm{C}$ storage. Bulgarian Journal of Agricultural Science. 17: 655-663.

Javale, P. and Sabnis, S. 2010.Antimicrobial properties and phytochemical analysis of Emblica officinalis. Asian Journal of Experimental Biological Sciences. 9195. 
Kahkonen, M. P., Hopia, A.I., Vuorela, H. J., Rauha, J., Pihlaja, K., Kujala, T. S. and Heinonen, M. 1999. Antioxidant activity of plant extracts containing phenolic compounds. Journal of Agricultural and Food Chemistry. 47: 3954-3962.

Karabagias, I., Badeka, A. and M. G. Kontominas. 2011. Shelf life extension of lamb meat using thyme or oregano essential oils and modified atmosphere packaging. Meat Science. 88: 109-116.

Khopde, S. M., Priyadarsini, K. I., Mohan, H., Gawandi, V. B., Satav, J. G., Yakhmi, J. V., Banavaliker, M. M., Biyani, M. K. and Mittal, J. P. 2001. Characterizing the antioxidant activity of amla (Phyllanthusemblica) extract. Current science. 81(2): 185-190.

Kumar, V., Chatli, M. K., Wagh, R. V., Mehta, N. and Kumar, P. 2015. Effect of the combination of natural antioxidants and packaging methods on quality of pork patties during storage. Journal of Food Science and Technology.52(10): 6230 6241.

Leheska, J. M., Boyce, J., Brooks, J. C., Hoover, L. C., Thompson, L. D. and Miller, F. 2006. Sensory attributes and phenolic content of precooked pork breakfast sausage with fruit purees. Journal of Food Science. 71: 249-S252.

Liu, X., Cui, C., Zhao, M., Wang, J., Luo, W; Yang, B. and Jiang, Y. 2008. Identification of phenolics in the fruit of Emblica (Phyllanthusemblica.) and their antioxidant activities, Food Chemistry. 109: 909-915.

Luqman, S. and Kumar, R. 2012. Correlation between scavenging property and antioxidant activity in the extracts of Emblica officinalisGaertn., syn. Phyllanthus emblica L. Fruit. Annals of Phytomedicine.1(1): 54-61.

Mehrotra, S., Srivastava, A. K. and Nandi, S. P. 2010. Comparative antimicrobial activities of Neem, Amla, Aloe, Assam Tea and Clove extracts against Vibrio cholerae, Staphylococcus aureusand
Pseudomonas aeruginosa. Journal of Medicinal Plants Research. 4(18):24732478.

Mehta, N., Sharma, B. D., Kumar, R. R., Kumar, P., Malav, O. P. and Verma, A. K. 2015. Fortification of low-fat chicken meat patties with calcium, vitamin $E$ and vitamin $C$. Nutrition \& Food Science, 45 (5), 688-702.

Mielnik, M.B., Olsen, E., Vogt, G., Adeline, D. and Skrede, G. (2006). Grape seed extract as antioxidant in cooked, cold stored turkey meat. Food Science and Technology. 39:191-198.

Mishra, P. and Mahanta, C. L. 2014. Comparative analysis of functional and nutritional value of amla (Emblica officinalis) fruit, seed and seed coat powder. American Journal ofFood Technology. 9(3): 151-161.

Najeeb, A. P., Mandal, P. K. and Pal, U. K. 2014. Efficacy of fruits (red grapes, gooseberry and tomato) powder as natural preservatives in restructured chicken slices. International FoodResearch Journal. 21(6): 24312436.

Naveena, B.M., Sen, A.R., Vaithiyanathan, S., Babji, Y. and Kondaiah, N. (2008). Comparative efficacy of pomegranate juice, pomegranate rind powder extract and BHT as antioxidants in cooked chicken patties. Meat Science. 80:13041308.

Negi, P. S. and Jayaprakasha, G. K. 2003. Antioxidant and antibacterial activities of Punica granatum peel extracts. Journal of Food Science. 68: 14731477.

Patil, S. G., Deshmukh, A. A., Padol, A. R. and Kale, D. B. 2012. In vitro antibacterial activity of Emblica officinalis fruit extract by tube Dilution Method. International Journal of Toxicology and Applied Pharmacology. 2(4): 49-51.

Rajkumar, V., Agnihotri, M. K. and Sharma, N. (2004). Quality and shelf life of vacuum and aerobic packed chevon patties under refrigeration. Asian-Australasian 
Journal of Animal Sciences.17(4): 548553.

Saiga, A., Okumura, T., Makihara, T., Katsuta, S., Shimizu, T. and Yamada, R. 2003.Angiotensin I converting enzymes inhibitory peptides in a hydrolyzed chicken breastmuscle extract. Journal of Agricultural and Food Technology. 51: 174-175.

Serdaroglu, M., Ergezer, H. and Akcan, T. 2015. Evaluation of the antioxidant potential of artichoke (cynarascolymus l.) byproducts extracts in raw beef patties. In: 57th international conference of meat science and technology, Ghent, Belgium, august, 7-12, 2011. Curran associates, Inc. pp. 63-66.

Sinhamahapatra, M., Bhattacharyya, D. and Biswas, S. 2013. Extension of shelf life of chicken meat ball by adopting combination of Packaging technique and storage temperature. International Journal of Development Research. 3(5): 61-66.

Snedecor, G. W. and Cochran, W. G. 1989. Statistical methods. $8^{\text {th }}$ ed. IOWA state university press, Ames, IOWA.

Tarladgis, B. G., Watts, B. M., Yaunathan, M. T. and Dugan, L. R. 1960. Distillation method for the quantitative determination of malonaaldehyde in rancid foods. Journal of American Oil Chemists Society. 37: 66-71
Thomas, R., Anjaneyulu, A.S.R. and Kondaiah, N. 2006. Quality and shelf life evaluation of emulsion and restructured buffalo meat nuggets at cold storage $\left(4 \pm 1^{\circ} \mathrm{C}\right)$. Meat Science. 72 : 373-379.

Trout, E.S., Hunt, M.C., Jhonson, D.E., Clans, J.R.,Castner, C.L. and Kropf, D.H. 1992. Characterization of low fat ground beef containing texture modifying ingredients. Journal of Food Science.57(1):19-24.

Vercruysse, L., Van Camp, J. and Smagghe, G. J. 2005 ACE Inhibition pepties derived from enzymetic hydrolysates of animal muscle protein: A review. Journal of Agricultural andFood Chemistry. 53: 8106-8115.

Verma, A. K., Rajkumar, V., Banerjee, R., Biswas, S. and Das, A. K. 2013. Guava (Psidium guajava) powder as an Antioxidant dietary fibre in sheep nuggets. Asian-Australasian Journal of Animal Sciences. 26(6): 886-895.

Witte, V. C.,Krouze, G.F. and Bailey, M.E. 1970.Anew extraction method for determining 2-thiobabituric acid values of pork and beef during storage. Journal of Food Science. 35:582-585.

Zargar, F. A., Kumar, S., Bhat, Z. F. and Kumar, P. 2014. Effect of pumpkin on the quality characteristics and storage quality of aerobically packaged chicken sausages. Springer Plus. 3:39.

\section{How to cite this article:}

Bariya, A.R., A.S. Patel, V.V. Gamit, K.R. Bhedi and Parmar, R.B. 2018. Assessment of Antioxidant and Sensory Properties of Amla (Emblica officinalis) Fruit and Seed Coat Powder Incorporated Cooked Goat Meat Patties. Int.J.Curr.Microbiol.App.Sci. 7(07): 3306-3318. doi: https://doi.org/10.20546/ijcmas.2018.707.385 